\title{
DECISION MAKING OF HAND TRACTOR GEAR BOX DESIGNS
}

\author{
AHMAD FATIH FUDHLA \\ Systems Modeling Laboratory, Industrial Engineering Department, STT YPM \\ Raya Ngelom 86, Taman, Sepanjang, Sidoarjo 61257, East Java, Indonesia \\ Email: fudhla04@yahoo.co.id
}

\begin{abstract}
ABSTRAK
Pengambilan keputusan dalam memilih desain pengembangan komponen Gear Transmission box (GTB) pada Traktor Tangan dilakukan dengan banyak kriteria. Berdasarkan diskusi Focus group dan brainstorming yang dilakukan oleh tim pengembangan produk, teridentifikasi tujuh kriteria yakni; Ketahanan material terhadap korosi, Kemampuan desain untuk diproses di lantai produksi, kemampuan desain dalam menahan beban operasi maksimum traktor tangan, pengaruh terhadap proses produksi komponen lainnya, biaya manufaktur, massa desain GTB, dan waktu proses. Kriteria tersebut dikelompokkan ke dalam kategori positif dan negative. Positif adalah kriteria yang nilainya semakin besar semakin baik, sedangkan negatif semakin kecil semakin baik. Terdapat tiga alternatif desain, yakni Desain Awal, Desain 1 dan Desain 2. Pemilihan dilakukan dengan metode Analytic Hierarchy Process (AHP). Evaluasi dilaksanakan terpisah untuk kedua kategori. Alternative terbaik adalah alternative yang memiliki nilai perbandingan terbesar antara nilai alternatif criteria positif dan negative.
\end{abstract}

Kata Kunci: Analytical Hierarchy Process, Perbandingan Berpasangan, Perancangan dan Pengembangan Komponen Produk

\begin{abstract}
Decision making on selection of hand tractor Gear Transmission Box (GTB) "Improvement Designs" is carried out according to many criteria. Based on the focus group and brainstorm performed by product-development teams, seven criteria are finally identified as follows; Material corrosion resistance, Manufacturability, The ability of the design to withstand the maximum load operation, influence on the other components process, manufacturing cost, mass of GTB design, and processing time. Those criteria are categorized into positive and negative characteristics. Positive criteria indicate that score which is the greater the better, by contrast, negative is the less the better. There are 3 alternatives namely Initial Design, Design 1 and Design 2. The selection is performed based on Analytic Hierarchy Process (AHP) Method. The evaluation is analyzed separately according to each category. The best alternative is the one which has the highest ratio between positive and negative criteria.
\end{abstract}

Key Words: Analytical Hierarchy Process, Pair-wise Comparison, Component Design and Development

\section{INTRODUCTION}

In a product/component development project, the various designs can be produced. Since the difficulty of evaluation criteria determination and the complexity of product coverage exist, the assessment and consideration of decision making tend to be bias and subjective. These reasons trigger decision maker assess and consider the choice intuitively (Luo et al., 2008). On the other hand, failure on fabrication frequently occurs because of the deficient in deciding the best of them (Atuahene-Gima and Li, 2004). Design selection should be performed carefully, comprehensively and inwrought in order to minimize risk of development failure.

Many decision making tools/ models have been applied for the selection of a suitable design. Based on the literature review established by Seram (2013), decision making tools which are commonly used can be mentioned as follows: Technique For Order Performance by Similarity to Ideal Solution (TOPSIS), AHP and TOPSIS, 
Decision Matrix (DM) and Robust design (RD), value analysis/ engineering (VA/VE), design for $\mathrm{X}$ (DFX), axiomatic design (AD) by Coelho and Mourao (2007) which shows how AD allows for perceiving the relationships between each product and the related manufacturing processes, Cariaga et al. (2007) Integrating QFD, Value analysis (VA) and data envelopment analysis (DEA) used on a high-tech research facility construction project, and Barajas and Agard (2008) applied Fuzzy Decision-Making for product selection.

In mechanical components design and development, Technical aspects and capabilitiesprocess become important points for the selection consideration (Rosen et al., 2012; Boothroyd and Dewhurst, 2002). There are technical aspects which are able to be quantified with engineering consideration, but there are other aspects can be appeared which are qualitative and intangible such how to determine the importance of the selection criteria. Both aspects must be evaluated. In view of this purpose, The Analytic Hierarchy Process (AHP) does seem useful (Battistoni et al., 2013). AHP is a theory of decision making which uses pairwise comparison matrix and relies on the judgments of experts in order to derive priority scales. It is these scales that measure intangibles in relative terms. The comparison matrices are constructed by using a scale of absolute judgment that represents how big one element dominates other with respect to a given attribute (Saaty, 2008).

This paper deals with the implementation of AHP in order to find an appropriate alternative related to design development of mechanical component; a pair of Gear Transmission Box (GTB). This research provides evidence that multi criteria analysis is very useful in making a decision for Product Development Engineer in the preeminent design selection.

\section{METHODS}

\section{Analytic Hierarchy Process (AHP)}

AHP was introduced by Thomas L. Saaty and designed to solve complex problem entangling many criteria. The Analytic Hierarchy Process (AHP) is a structured technique for dealing with complex decisions. Based on mathematics and human psychology, The AHP provides a comprehensive and rational framework for structuring a problem, for representing and quantifying its elements, for relating those elements to overall goals, and for evaluating alternative solutions. Qualitative attributes are changed into quantitative in a pair-wise comparison set as presented in Table 1 (Saaty, 2008).

Since using human perception, AHP model can incorporate data both qualitative and quantitative. So complexity of problems can be tackled well by using AHP model. In addition,

Table 1. AHP Scale and Definition pairwise comparison set (Saaty, 2008)

\begin{tabular}{cl}
\hline Intensity & \multicolumn{1}{c}{ Definition and Explanation of "Importance" } \\
\hline 1 & $\begin{array}{l}\text { Equal Importance. Two risk factors contribute equally to risk. } \\
\text { Weak importance of one. Experience and judgment to be slightly more important than } \\
\text { another. }\end{array}$ \\
5 & $\begin{array}{l}\text { Essential or strong. Experience and judgment indicate one risk factor to be strongly } \\
\text { more important than another. }\end{array}$ \\
7 & $\begin{array}{l}\text { Very strong or demonstrated importance/Significantly more Importance. A risk factor } \\
\text { is very strongly more important than another; its dominance demonstrated in practice. } \\
\text { Absolute importance. The evidence of the importance of one risk factor over another is } \\
\text { of the highest possible order of affirmation. } \\
\text { Compromise values. Intermediate values between adjacent scale values When } \\
\text { compromise is needed }\end{array}$ \\
\hline
\end{tabular}




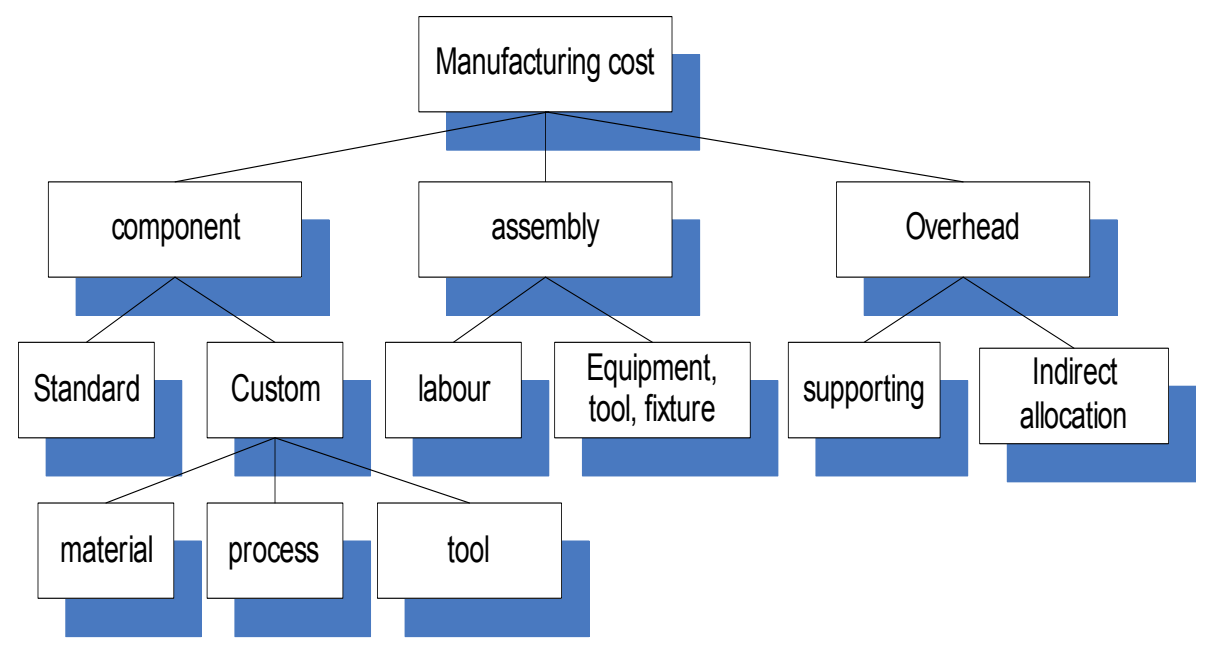

Figure 1. Manufacturing cost elements

Source: Ulrich and Eppinger, 2000

AHP has capability to solve multi-objective and multi criteria problems based on the preference comparison of each element in the hierarchy. In AHP, Consistency test and sensitivity analysis are emerged to perceive the reliable judgment because as we know that the judgment relies on the expert's opinion which is possibly inconsistent at any time. Consistency test is addressed for priority hierarchy that was built.

Generally, consistency test is performed by using Consistency Ratio (CR). If the value of Consistency Ratio is smaller or equal to $10 \%$, the inconsistency is acceptable. If the Consistency Ratio is greater than $10 \%$, we need to revise the subjective judgment (Saaty, 1990). CR is calculated by dividing Consistency Index (CI) with Consistency Random Index (RI) (see Table 2). Consistency Index (CI) is calculated based on the maximum Eigen value. All the equation as shown below;

$\lambda=\frac{\sum_{i=1}^{\mathrm{n}} \mathrm{a}_{\mathrm{li}} \cdot \mathrm{p}_{\mathrm{i}}}{\mathrm{p}_{1}}$

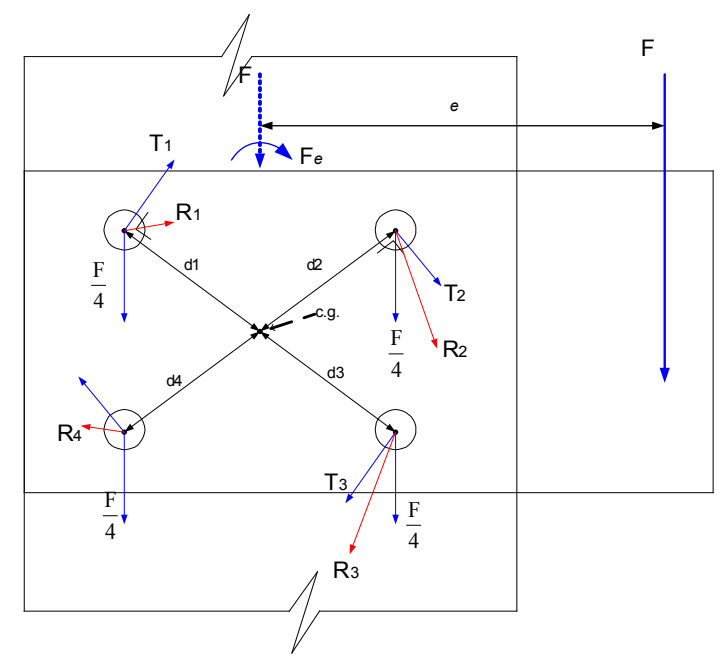

Figure 2. Free body diagram of twisting, direct and resultant forces acting on rivets and due to the gusset plate

comparison of element 1 to element $i, p_{i}$ is priority or weight of element $\mathrm{i}$

$\mathrm{CI}=\frac{\lambda_{\max }-\mathrm{n}}{\mathrm{n}-1}$

Table 2. Consistency Random Index

\begin{tabular}{ccccccccccc}
\hline $\mathrm{n}$ & 1 & 2 & 3 & 4 & 5 & 6 & 7 & 8 & 9 & 10 \\
\hline $\mathrm{RI}$ & 0 & 0 & 0.58 & 0.90 & 1.12 & 1.24 & 1.32 & 1.41 & 1.45 & 1.49 \\
\hline
\end{tabular}

Source: Saaty, 1990 


$$
\mathrm{CR}=\frac{\mathrm{CI}}{\mathrm{RI}}
$$

Where; CI is consistency Index, $\lambda_{\max }$ is maximum eigen value, $\mathrm{n}$ is number of compared element, CR is consistency Ratio and RI is Consistency Random Index (value for each comparison number is shown in Table 2)

\section{Manufacturing Cost}

According to Ulrich and Eppinger (2000) manufacture cost of a product classified into 3 categories, they are:

1. Component cost

2. Assembly cost

3. Overhead cost

manufacturing cost = component + assembly cost + overhead cost

In addition, the element of each category can be seen in Figure 1. Component costs include standard component cost and custom component cost. Standard components are the items which have been standardized in terms of shape, measure or materials such as shovel, bolt, and pipe. Whereas custom components are the items which are made based on the design regardless of standardization. Assembly costs include workers' wage cost and equipment cost. Overhead cost is a category which represents another cost besides Component and Assembly Cost. It involves two elements: support and indirect allocation. (Ulrich and Eppinger, 2000)

\section{Eccentrical Loaded bolt/rivet}

GTB needs many mechanical analyses for the best performance of the design. Load analysis is used to find-out how many and how big loadforce must be shored up by GTB. It is useful in measuring design strength.

According to Norton (2014), based on law of static; a force may be moved to a parallel coplanar position by replacing it by an equivalent force and couple, F (solid line) is replaced by the equivalent force $\mathrm{F}$ (dotted), acting through the center of gravity of rivet group, and equivalent couple Fe like shown in Figure 2.F(dotted) are apportionment to each rivet given by,

$$
F_{1}(\text { dotted })=F_{2}(\text { dotted })=F_{n}(\text { dotted })=\frac{F}{n}
$$

And Forces $\left(\mathrm{T}_{\mathrm{j}}\right)$ caused by couple $\mathrm{Fe}$, given $\mathrm{b}$ $T_{j}=\frac{F e d_{j}}{\sum_{k=1}^{n} d_{k}^{2}}$

Where $e$ is horizontal distance to rivet systems center of gravity in meter, $\mathrm{F}$ is an eccentric force that causes load in rivets systems in Newton and $d_{k}$ is variable that show distance each rivet to center of gravity of rivet systems in meter.

\section{Loads in Bearing because rotation of gear and shaft}

Load in bearing that caused by power transmitted consist of two forces. Tangential force $\left(F_{t}\right)$ and radial force $\left(F_{r}\right)$ (Norton, 2014). Tangential direction is the axis heading to the center of bearing whereas radial force direction is opposite with radial movement. Both are given by

$F_{r}=F_{t} \tan \Phi$

$F_{t}=\frac{(\mathrm{hp})(33000)}{V_{p}}$

And Pitch velocity $\left(\mathrm{V}_{\mathrm{p}}\right)$ is given by

$V_{p}=\frac{\pi d n}{12}$

Torsion (T) And power that transmitted (hp) given by

$h p=\frac{T n}{63000}$

Where $\Phi$ is pressure angle of gear in degree, $\mathrm{hp}$ is power transmitted by gear in horse power, torsion ( $\mathrm{T}$ ) in inches-pound, angular velocity $\mathrm{n}$ in rpm, gear diameter $d$ in inches, $V_{p}$ in $\mathrm{ft} / \mathrm{min}$, $\mathrm{F}_{\mathrm{t}}$ and $\mathrm{F}_{\mathrm{r}}$ in $\mathrm{lbf}$.

\section{Processing Time (machining time)}

Design is fabricated through two machining processes which are fraise and drilling. Singal et al. (2008) explained that cutting time $\left(t_{c}, \min \right)$ for 
fraise depends on length of cutting track $\left(\mathrm{l}_{\mathrm{t}}, \mathrm{mm}\right)$ and cutting speed $\left(\mathrm{v}_{\mathrm{f}}, \mathrm{mm} / \mathrm{min}\right)$ that are given by,

$\mathrm{t}_{\mathrm{c}}=\mathrm{l}_{\mathrm{t}} / \mathrm{v}_{\mathrm{f}}$

$l_{\mathrm{t}}=l_{\mathrm{v}}+1_{\mathrm{w}}+l_{\mathrm{n}}$

Where $l_{v}$ is starting track in $m m$ and $l_{n}$ is finishing track in $\mathrm{mm}$.

$l_{v} \geq \sqrt{a(d-a)} \quad ;$ for horizontal fraise

$l_{v} 30 \sqrt{a}$; for vertical fraise

$\mathrm{v}^{3} 0$; for horizontal fraise

$l_{n}=\mathrm{d} / 2 ;$ for vertical fraise

Similar with fraise process, cutting time of drilling and boring process are given by feeding speed $\left(\mathrm{f}_{\mathrm{z}}, \mathrm{mm} /\right.$ rotation) for each tool

$\mathrm{f}_{\mathrm{z}}=\mathrm{v}_{\mathrm{f}} /(\mathrm{n} . \mathrm{z}) ; \mathrm{z}=2$

Cutting time $\left(\mathrm{t}_{\mathrm{c}}, \mathrm{min}\right)$ :

$\mathrm{t}_{\mathrm{c}}=\mathrm{l}_{\mathrm{t}} / \mathrm{v}_{\mathrm{f}}$

$l_{\mathrm{t}}=1_{\mathrm{v}}+1_{\mathrm{w}}+1_{\mathrm{n}}$

Total machining time can be derived by summing nonproductive time $\left(t_{a}\right)$, tool changing time $\left(\mathrm{t}_{\mathrm{d}}\right)$ and cutting time $\left(\mathrm{t}_{\mathrm{c}}\right)$.

$\mathrm{t}_{\mathrm{o}}=\mathrm{t}_{\mathrm{a}}+\mathrm{t}_{\mathrm{d}}+\mathrm{t}_{\mathrm{c}}$

\section{Cutting Metal Plate and Forming Force}

The piercing process is cutting process where resulted part in the inside of cutting line. Very important factor this process is shearing resistance (Ks) got from maximum amputation style $(\mathrm{Fs})$. Shearing Resistance $(\mathrm{Ks})$ is factor influenced by factor clearance between punch and dies, tool worn-down, material characteristic, thickness of sheet and form of the blank. Ks must be bigger than maximum tension shift so that the material can be cut. Maximum tension shift of material is equal to $0,8 \sigma_{u}$ (ultimate tensile stress of material). Forces needed for piercing and blanking process can be determined by using the following equation;

Fs $=$ Ls. So. Ks

Where, Fs is cutting Force in $\mathrm{kg}$, Ls is circumference of cutting line in $\mathrm{mm}$, So is thickness of material in $\mathrm{mm}$, and $\mathrm{Ks}$ is shearing resistance equal to $0,8 \sigma_{\mathrm{u}}$ in $\mathrm{kg} / \mathrm{mm}^{2}$

A Simple equation is used to determine forming force of bending;

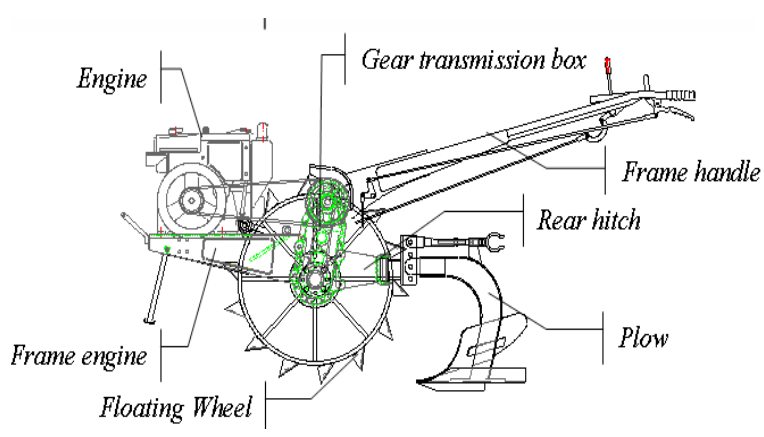

Figure 3. Seven main components of hand tractor

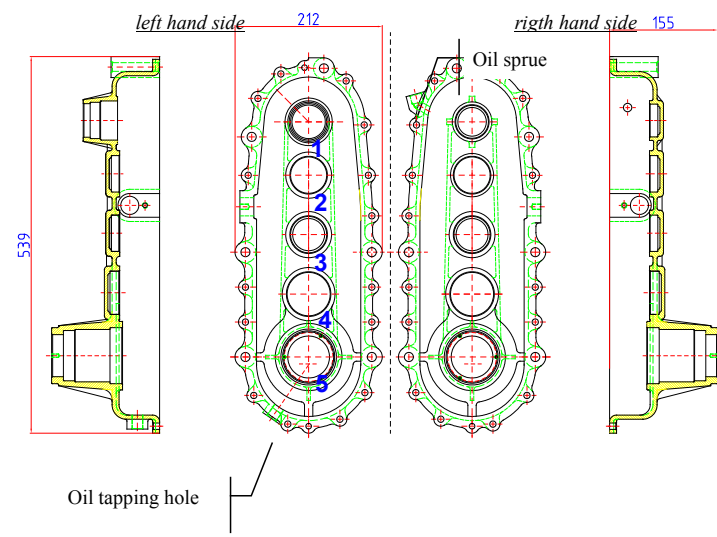

Figure 4. Initial Design of GTB

Table 3. Manufacturing Cost Initial Design

\begin{tabular}{lcccccc}
\hline $\begin{array}{c}\text { Part } \\
\text { Name }\end{array}$ & $\begin{array}{c}\text { Material } \\
\text { Cost }\end{array}$ & $\begin{array}{c}\text { Machining } \\
\text { Cost }\end{array}$ & $\begin{array}{c}\text { Machining Labour } \\
\text { Cost }\end{array}$ & $\begin{array}{c}\text { Assembly } \\
\text { Cost }\end{array}$ & $\begin{array}{c}\text { Overhead } \\
\text { Cost }\end{array}$ & $\begin{array}{c}\text { Manufacturing } \\
\text { Cost }\end{array}$ \\
\hline GTB LH & 164,500 & $11,149.2$ & $30,917.3$ & 0.0 & $12,431.7$ & $218,998.2$ \\
GTB RH & 163,500 & $9,229.0$ & $26,224.2$ & 0.0 & $11,720.3$ & $210,673.5$ \\
Total & 328,000 & $20,378.2$ & $57,141.5$ & 0.0 & $24,152.0$ & $429,671.7$ \\
\hline
\end{tabular}


$P_{s}=\frac{\sigma_{0} \cdot L \cdot s_{0}^{2}}{2\left(R+\frac{s_{0}}{2}\right)} \tan \frac{\alpha}{2}$

Where, $\mathrm{L}$ is length of bending area, $\sigma_{0}$ is yield strength of material, $\alpha$ is bending angle, $s_{0}$ is thickness of material, and $\mathrm{R}$ is radius of bending

\section{RESULT AND DISCUSSION}

GTB detain loads from another main component of hand tractor (figure 3). There are two kinds of load, statics and dynamics. Static loads are the loads caused by weight of other components. It consists of Frame handle $22 \mathrm{~kg}$, Frame engine and engine $116 \mathrm{~kg}$ Rear hitch and plow $34 \mathrm{~kg}$, floating wheel $52 \mathrm{~kg}$ and GTB net

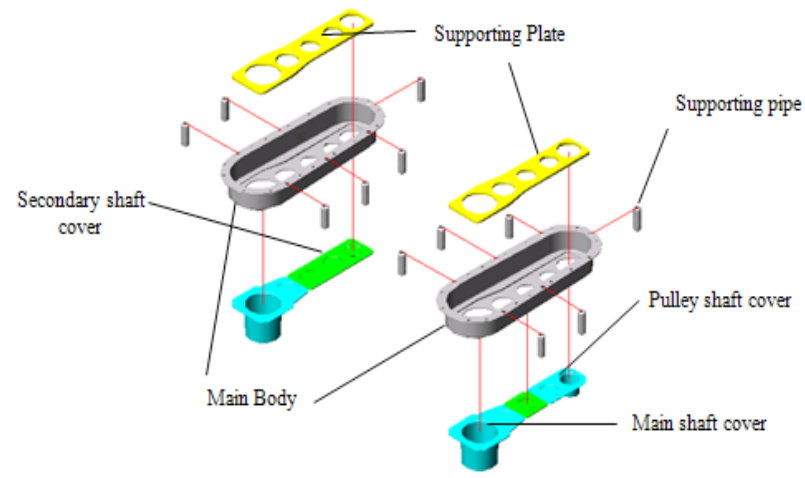

Figure 5. Design 1 of GTB

weight $36 \mathrm{~kg}$. Dynamic loads are the loads caused by rotation of gear systems. Maximum load is the biggest resultant of dynamic and static loads.

Table 4. Processing step of Design 1

\begin{tabular}{|c|c|c|}
\hline No & GTB LH & GTB RH \\
\hline 1 & Welding Plate Support assy & Welding Plate Support assy \\
\hline 2 & Welding 6 part tube support assy & Welding 6 part tube support assy \\
\hline 3 & Full side freis mill & Full side freis mill \\
\hline 4 & Drilling 2 pen holes & Drilling 2 pen holes \\
\hline 5 & Full side freis mill & Full side freis mill \\
\hline 6 & Boring + Chamfering 5 holes together & Boring + Chamfering 5 holes together \\
\hline 7 & Drilling oil taping & Drilling 6 holes $\varnothing 7$ \\
\hline 8 & Drilling oil Sprue & Drilling 6 holes $\varnothing 8$ \\
\hline 9 & Drilling 8 holes $\varnothing 7$ & Drilling 6 holes $\varnothing 10$ \\
\hline 10 & Drilling 6 holes $\emptyset 8$ & Drilling 15 holes $Ø 8$ \\
\hline 11 & Drilling 6 holes $\emptyset 10$ & Drilling 6 holes main shaft cover \\
\hline 12 & Drilling 15 holes $\varnothing 8$ & Drilling 3 holes secondary shaft cover $\mathrm{RH}$ \\
\hline 13 & Drilling 6 holes main shaft cover & Main body forming \\
\hline 14 & Drilling 3 holes secondary shaft cover LH & Plate support forming \\
\hline 15 & Drilling 6 holes pulley shaft cover LH & Main shaft cover forming \\
\hline 16 & Main body forming & Secondary shaft cover forming $\mathrm{RH}$ \\
\hline 17 & Plate support forming & Tube support cutting \\
\hline 18 & Main shaft cover forming & Freis main shaft cover \\
\hline 19 & Secondary shaft cover forming $\mathrm{LH}$ & \\
\hline 20 & Pulley shaft cover forming & \\
\hline 21 & Tube support cutting & \\
\hline 22 & Freis main shaft cover & \\
\hline 23 & Freis pulley shaft cover & \\
\hline
\end{tabular}


Table 5. Design 1 manufacturing cost recap

\begin{tabular}{lcccccc}
\hline \multicolumn{1}{c}{ Part Name } & $\begin{array}{c}\text { Material } \\
\text { Cost }\end{array}$ & $\begin{array}{c}\text { Machining } \\
\text { Cost }\end{array}$ & $\begin{array}{c}\text { Labour } \\
\text { Cost }\end{array}$ & $\begin{array}{c}\text { Assy } \\
\text { Cost }\end{array}$ & $\begin{array}{c}\text { Overhead } \\
\text { Cost }\end{array}$ & $\begin{array}{c}\text { Manufacturing } \\
\text { Cost }\end{array}$ \\
\hline GTB LH & $92,815.81$ & $32,035.61$ & $30,929.11$ & $3,854.41$ & $11,200.61$ & $170,835.54$ \\
GTB RH & $85,341.21$ & $26,638.91$ & $26,364.21$ & $3,854.41$ & $9,830.71$ & $152,029.44$ \\
Total & $178,157.01$ & $58,674.51$ & $57,293.31$ & $7,708.81$ & $21,031.31$ & $322,864.97$ \\
Total after depress. & $178,157.01$ & $59,374.51$ & $57,293.31$ & $7,708.81$ & $21,031.31$ & $322,864.97$ \\
$\quad$ Cost (Rp 700.- in & & & & & & \\
$\quad$ machining cost) & & & & & & \\
\hline
\end{tabular}

By using equation (5), (6), (7), (8), (9) and (10), maximum load can be calculated. It is $57.06 \mathrm{kN}$ in GTB RH.

\section{Initial Design}

As shown in Figure 4, Initial Design consists of two parts; GTB RH and GTB LH. Initially,
GTB are processed by combination of casting and machining process. Casting is performed by subcontractor and machining is performed in its shop. GTB has $36 \mathrm{~kg}$ mass.

The material is made from cast iron FC25. The design has capability to detain maximum operation load till $211.7 \mathrm{kN}$. Processing time

Table 6. Processing step of Design 2

\begin{tabular}{|c|c|c|}
\hline No & GTB LH & GTB RH \\
\hline 1 & Welding Main Body B-C Assy & Welding Main Body B-C Assy \\
\hline 2 & Welding Main Body A-(BC) Assy & Welding Main Body A-(BC) Assy \\
\hline 3 & Welding 6 part tube support assy & Welding 6 part tube support assy \\
\hline 4 & Fullside freis mill & Fullside freis mill \\
\hline 5 & Drilling 2 pen holes & Drilling 2 pen holes \\
\hline 6 & Boring + Chamfering 5 holes together & Boring + Chamfering 5 holes together \\
\hline 7 & Drilling oil taping & Drilling 6 holes $\varnothing 7$ \\
\hline 8 & Drilling oil Sprue & Drilling 6 holes $\varnothing 8$ \\
\hline 9 & Drilling 8 holes $\emptyset 7$ & Drilling 6 holes $\emptyset 10$ \\
\hline 10 & Drilling 6 holes $\varnothing 8$ & Drilling 15 holes $\emptyset 8$ \\
\hline 11 & Drilling 6 holes $\varnothing 10$ & Drilling 6 holes main shaft cover \\
\hline 12 & Drilling 15 holes $\emptyset 8$ & drilling 3 holes secondary shaft cover $\mathrm{RH}$ \\
\hline 13 & Drilling 6 holes main shaft cover & Main body forming (A and B) \\
\hline 14 & drilling 3 holes secondary shaft cover LH & Main body forming (C) \\
\hline 15 & Drilling 6 holes pulley shaft cover LH & main shaft cover forming \\
\hline 16 & Main body forming (A and B) & secondary shaft cover forming $\mathrm{RH}$ \\
\hline 17 & Main body forming $(\mathrm{C})$ & tube support cutting \\
\hline 18 & main shaft cover forming & freis main shaft cover \\
\hline 19 & secondary shaft cover forming $\mathrm{LH}$ & \\
\hline 20 & Pulley shaft cover forming & \\
\hline 21 & tube support cutting & \\
\hline 22 & freis main shaft cover & \\
\hline 23 & freis pulley shaft cover & \\
\hline
\end{tabular}




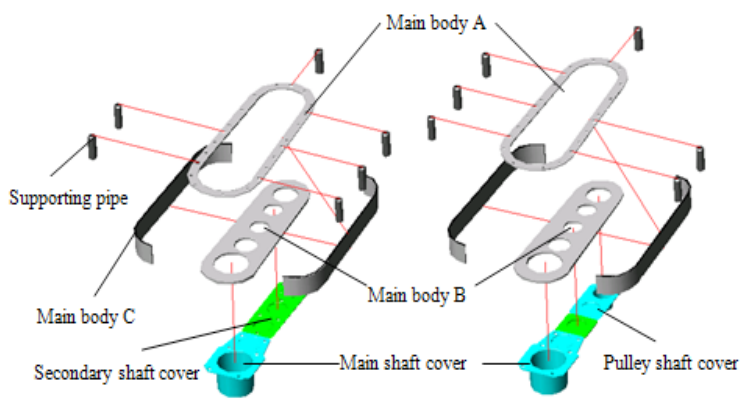

Figure 6. Design 2 of GTB

per pair unit (casting + machining) is 898.65 minutes.

By using equation 4, the manufacturing cost is calculated based on component costs, assembly costs and overhead costs. Component cost consists of material cost, machining cost and machining labour cost. (Shown in Table 3). Overhead rate is estimated as $5 \%$ of material cost and $10 \%$ of machining, labour and assembly cost. Total manufacturing cost for initial design is $\mathrm{Rp}$ 429,671 .

\section{Design 1}

Design 1 uses ST 37 material. Main body consists of a part. Thickness of main body is 3.2 $\mathrm{mm}$. there is supporting plate $8 \mathrm{~mm}$ thickness in every side of GTB. This design consists of 11 parts in a side. (Shown in Figure 5).

GTB are produced by combination of metal forming, welding and machining all in its own shop. There are 5 metal forming operations, 16 machining and 2 assembly operations in GTB LH. In other sides there are 4 metal forming operations,

Table 7. Design 2 manufacturing cost recapitulation

\begin{tabular}{lcccccc}
\hline \multicolumn{1}{c}{ Part Name } & $\begin{array}{c}\text { Material } \\
\text { Cost }\end{array}$ & $\begin{array}{c}\text { Machining } \\
\text { Cost }\end{array}$ & $\begin{array}{c}\text { Labor } \\
\text { Cost }\end{array}$ & Assy Cost & $\begin{array}{c}\text { Overhead } \\
\text { Cost }\end{array}$ & $\begin{array}{c}\text { Manufacturing } \\
\text { Cost }\end{array}$ \\
\hline GTB LH & $90,857.80$ & $35,586.60$ & $31,229.70$ & $7,280.00$ & $11,864.20$ & $176,818.30$ \\
GTB RH & $93,332.10$ & $30,195.10$ & $26,681.90$ & $7,280.00$ & $10,994.00$ & $168,483.10$ \\
Total & $184,189.90$ & $65,781.70$ & $57,911.60$ & $14,560.00$ & $22,858.20$ & $345,301.39$ \\
Total after depres. & $184,189.90$ & $66,231.70$ & $57,911.60$ & $14,560.00$ & $22,858.20$ & $345,301.39$ \\
$\quad$ Cost (Rp 400 in & & & & & & \\
$\quad$ machining cost) & & & & & & \\
\hline
\end{tabular}

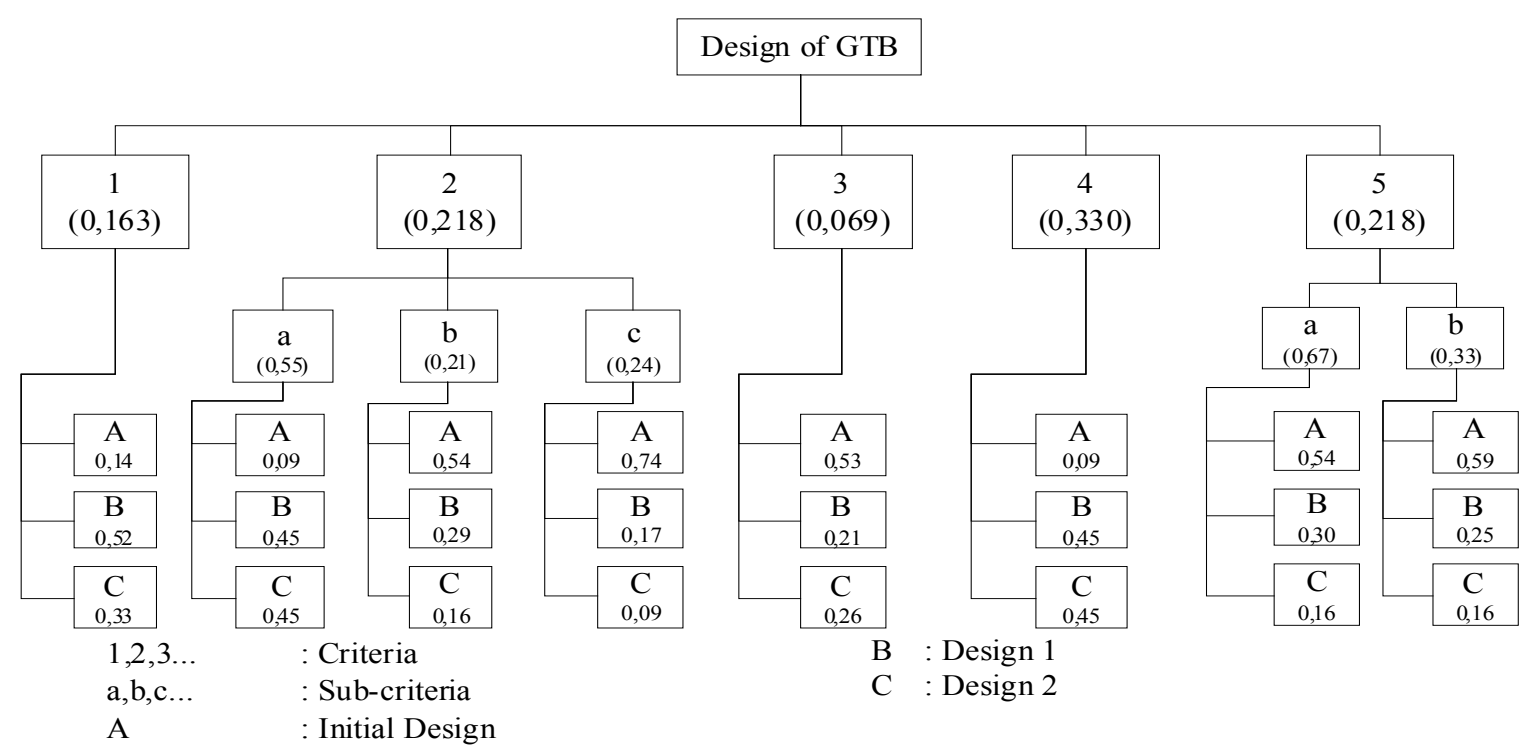

Figure 7. Priority Hierarchy for positive criterion 
12 machining and 2 assembly operations. All of them are shown in Table 4 above. Both sides have total $22 \mathrm{~kg}$ mass.

The design has capability to detain maximum operation load till 118,8 kN. By using equation 11, $12,13,14,15,16$ and sequential process in Table 3 , processing time per pair units is 518.14 minutes. And by equation 17 and 18 maximum forming force in supporting plate forming is 471.5 tons.

Design 1 requires investment dies for plate metal forming at 14 million rupiahs. This will be replaced each time to produce 20000 pairs of products. So, depreciation cost for design 1 ad per pair-unit by Rp 700.-. Manufacturing cost for Design 1 is Rp $322,864.97$

\section{Design 2}

Similar with Design 1, Design 2 uses ST 37 plate as material. Thickness of main body is 6 $\mathrm{mm}$, main shaft cover and pulley shaft cover are $4.3 \mathrm{~mm}$, and secondary shaft cover is $2 \mathrm{~mm}$. As shown in Figure 6, Design 2 of GTB consists of 13 parts in each side.

The differences from Design 1 are; in this design, main body consists of three parts in each side which are main body A, B, and C. GTB are processed in workshop using combination plate metal forming (drawing, piercing, shearing, banding and blanking), welding and machining. These operations are shown in Table 6. Both sides have total $25 \mathrm{~kg}$ mass.

The design has capability to withstand maximum operation load till $131.6 \mathrm{kN}$. Processing time per pair units is 565.31 minutes. By using equation 17 and 18, the force in main body $\mathrm{A}$ and
B forming are obtained, where the maximum force is equal to 449.73 tons. Based on the analysis of the team, to produce Design 2, it takes an investment of 2 million rupiahs for main body $\mathrm{A}$ and $\mathrm{B}$ forming dies; main body $\mathrm{C}$ about 1.5 million rupiahs; main shaft cover and pulley shaft cover are respectively about 2 million rupiahs; and two secondary shaft covers count about 1 million. Total cost allocated for design 2 is 9.5 million rupiahs. If each die is replaced in every 20,000 units GTB, depreciation cost for design 2 ads per pair-unit by Rp 475.-. Manufacturing cost including depreciation of new equipment is $\mathrm{Rp}$ 345,301.39 which is shown in Table 7.

\section{Decision Analysis}

The best design selection is conducted by using Analytical Hierarchy Process (AHP). Synthesis of the evaluation criteria and pairwise comparison matrices including scoring alternative decision are conducted by the product development team which consists of senior mechanical engineer, senior design engineer, senior production engineer and senior purchasing staff. A focus group and brainstorm by product development teams identify seven criteria;

1. Material corrosion resistance

2. Manufacturability with sub-criteria;
a. Availability of Facility
b. Machining-ability
c. Assembling-ability

3. The ability of the design to withstand the maximum load operation

4. Influence on the other components processes

a. Others hand tractor component

b. Others product component

Table 8. Weight of five decision criteria

\begin{tabular}{ccccccccccccc}
\hline Criteria & $\mathbf{1}$ & $\mathbf{2}$ & $\mathbf{3}$ & $\mathbf{4}$ & $\mathbf{5}$ & & & $\mathbf{b}(\mathbf{i}, \mathbf{j})$ & & & $\boldsymbol{\Sigma}$ b & weight \\
\hline $\mathbf{1}$ & 1.0 & 0.5 & 2.0 & 1.0 & 0.5 & 0.2 & 0.1 & 0.1 & 0.3 & 0.1 & 0.8 & 0.16 \\
2 & 2.0 & 1.0 & 3.0 & 0.5 & 1.0 & 0.3 & 0.2 & 0.2 & 0.2 & 0.2 & 1.1 & 0.22 \\
3 & 0.5 & 0.3 & 1.0 & 0.2 & 0.3 & 0.1 & 0.1 & 0.1 & 0.1 & 0.1 & 0.3 & 0.07 \\
4 & 1.0 & 2.0 & 5.0 & 1.0 & 2.0 & 0.2 & 0.4 & 0.4 & 0.3 & 0.4 & 1.7 & 0.33 \\
5 & 2.0 & 1.0 & 3.0 & 0.5 & 1.0 & 0.3 & 0.2 & 0.2 & 0.2 & 0.2 & 1.1 & 0.22 \\
\hline total & 6.5 & 4.8 & 14.0 & 3.2 & 4.8 & & & & & total & 5.0 & \\
\hline
\end{tabular}


Table 9. Weight of sub-criteria 2

\begin{tabular}{|c|c|c|c|c|c|c|c|c|}
\hline Sub criteria & $\mathbf{a}$ & $\mathbf{b}$ & c & \multicolumn{3}{|c|}{$\mathbf{b}(\mathbf{i}, \mathbf{j})$} & $\Sigma \mathbf{b}$ & weight \\
\hline $\mathbf{a}$ & 1.0 & 3 & 2.0 & 0.5 & 0.6 & 0.50 & 1.6 & 0.548 \\
\hline b & 0.3 & 1.0 & 1.0 & 0.2 & 0.2 & 0.25 & 0.6 & 0.211 \\
\hline c & 0.5 & 1.0 & 1.0 & 0.3 & 0.2 & 0.25 & 0.7 & 0.241 \\
\hline total & 1.8 & 5.0 & 4.0 & & & Total & 3.0 & \\
\hline
\end{tabular}

Table 10. Weight ofsub-criteria 5

\begin{tabular}{|l|c|r|r|r|r|r|}
\hline \multicolumn{1}{|c|}{ Subcriteria } & $\mathbf{a}$ & $\mathbf{b}$ & \multicolumn{2}{c|}{$\mathbf{b}(\mathbf{i}, \mathbf{j})$} & $\Sigma \mathbf{b}$ & weight \\
\hline $\mathbf{a}$ & 1.0 & 2.0 & 0.7 & 0.7 & 1.3 & 0.667 \\
\hline $\mathbf{b}$ & 0.5 & 1.0 & 0.3 & 0.3 & 0.7 & 0.333 \\
\hline total & 1.5 & 3 & & total & 2 & \multicolumn{1}{|c}{} \\
\cline { 1 - 6 } & & &
\end{tabular}

Table 11. Alternatives Design Score under criterion1 (corrosion)

\begin{tabular}{|c|c|c|c|c|c|c|c|c|}
\hline & Initial & Design 1 & Design 2 & \multicolumn{3}{|c|}{$\mathbf{b}(\mathbf{i}, \mathbf{j})$} & $\Sigma \mathbf{b}$ & score \\
\hline Initial & 1.0 & 0.3 & 0.3 & 0.14 & 0.18 & 0.10 & 0.4 & 0.141 \\
\hline Design 1 & 3.0 & 1.0 & 2.0 & 0.43 & 0.55 & 0.60 & 1.6 & 0.525 \\
\hline \begin{tabular}{|l|} 
Design 2 \\
\end{tabular} & 3.0 & 0.5 & 1.0 & 0.43 & 0.27 & 0.30 & 1.0 & 0.334 \\
\hline total & 7.0 & 1.8 & 3.3 & & & Total & 3.0 & \\
\hline
\end{tabular}

5. Manufacturing cost

6. Mass of GTB design, and

7. Processing time.

In this paper, the criteria are distinguished into two types; positive criterion and negative criterion. Positive criterion means a criterion which is the greater the better. The criteria involved in this type are criteria 1,2,3,4, and 5 which are shown in figure 7.

\section{Weight of criteria:}

The following table shows pair-wise comparison matrix among five criteria.

By equation (1), (2) and (3), CR/Consistency Ratio can be calculated.

By equation 1, eigen value can be calculated;

$\lambda=\frac{\sum_{\mathrm{i}=1}^{\mathrm{n}} \mathrm{a}_{\mathrm{li}} \cdot \mathrm{p}_{\mathrm{i}}}{\mathrm{p}_{\mathrm{l}}}$

$\lambda_{1}=\frac{(1 \times 0.1632)+(0.5 \times 0.2184)+(2 \times 0.0698)+(1 \times 0.3302)+(0.5 \times 0.2184)}{0.1632}=5.216$

$\lambda_{2}=\frac{(2 \times 0.1632)+(1 \times 0.2184)+(3 \times 0.0698)+(0.5 \times 0.3302)+(1 \times 0.2184)}{0.2184}=5.209$

$\lambda_{3}=\frac{(0.5 \times 0.1632)+(0.3 \times 0.2184)+(1 \times 0.0698)+(0.2 \times 0.3302)+(0.3 \times 0.2184)}{0.0698}=5.204$

$\lambda_{4}=\frac{(1 \times 0.1632)+(2 \times 0.2184)+(5 \times 0.0698)+(1 \times 0.3302)+(2 \times 0.2184)}{0.3302}=5.196$

$\lambda_{5}=\frac{(2 \times 0.1632)+(1 \times 0.2184)+(3 \times 0.0698)+(0.5 \times 0.3302)+(1 \times 0.2184)}{0.2184}=5.209$

The biggest Eigen value (smax) is 5.216. Because there are five attributes, so $\mathrm{n}$ value is equal to 5 and Random consistency index (RI) $=1.12$ (Table 2). By using equation 2 and 3 , consistency index and consistency ratio can be calculated.

$$
\mathrm{CI}=0.0542 \quad \mathrm{CR}=\frac{0.0540}{1.12}=0.0482
$$

Because $\mathrm{CR}<10 \%$, the inconsistency is acceptable 
Table 12. Alternatives Score under sub-criteria $2 \mathrm{a}$

\begin{tabular}{|l|c|c|c|c|l|l|l|c|}
\cline { 2 - 9 } \multicolumn{1}{c|}{} & Initial & Design 1 & \multicolumn{2}{c|}{ Design 2 } & \multicolumn{3}{c|}{ b(i,j) } & \multicolumn{2}{c|}{$\Sigma$ b } & score \\
\hline Initial & 1.0 & 0.2 & 0.2 & 0.09 & 0.09 & 0.09 & 0.3 & 0.091 \\
\hline Design 1 & 5.0 & 1.0 & 1.0 & 0.45 & 0.45 & 0.45 & 1.4 & 0.455 \\
\hline Design 2 & 5.0 & 1.0 & 1.0 & 0.45 & 0.45 & 0.45 & 1.4 & 0.455 \\
\hline total & 11.0 & 2.2 & 2.2 & & & Total & 3.0 & \\
\cline { 1 - 10 } & & &
\end{tabular}

Table 13. Alternatives Score under sub-criterion $2 \mathrm{~b}$

\begin{tabular}{|c|c|c|c|c|c|c|c|c|}
\hline & Initial & Design 1 & Design 2 & \multicolumn{3}{|c|}{$b(\mathbf{i}, \mathbf{j})$} & $\Sigma \mathbf{b}$ & Score \\
\hline Initial & 1.0 & 2.0 & 3.0 & 0.55 & 0.57 & 0.50 & 1.6 & 0.539 \\
\hline Design 1 & 0.5 & 1.0 & 2.0 & 0.27 & 0.29 & 0.33 & 0.9 & 0.297 \\
\hline Design 2 & 0.3 & 0.5 & 1.0 & 0.18 & 0.14 & 0.17 & 0.5 & 0.163 \\
\hline total & 1.8 & 3.5 & 6.0 & & & Total & 3.0 & \\
\hline
\end{tabular}

Table 14. Alternatives Score under sub-criterion 2c

\begin{tabular}{|c|c|c|c|c|c|c|c|c|}
\hline & Initial & Design 1 & Design 2 & \multicolumn{3}{|c|}{$\mathbf{b}(\mathbf{i}, \mathbf{j})$} & $\Sigma \mathbf{b}$ & Score \\
\hline Initial & 1.00 & 5.00 & 7.00 & 0.75 & 0.77 & 0.70 & 2.2 & 0.738 \\
\hline Design 1 & 0.20 & 1.00 & 2.00 & 0.15 & 0.15 & 0.20 & 0.5 & 0.168 \\
\hline Design 2 & 0.14 & 0.50 & 1.00 & 0.10 & 0.08 & 0.10 & 0.3 & 0.094 \\
\hline total & 1.3 & 6.5 & 10.0 & & & Total & 3.0 & \\
\hline
\end{tabular}

\section{Weight of Sub-criteria 2 (Manufacturability)}

In the Following Table, pairwise comparison matrix for weight of sub-criteria 2 (Availability of Facility/a, Machining-ability/b, Assemblingability/c) is shown.

By equation (1), (2), and (3) Consistency Ratio is $2.62 \%$. Since CR is smaller than $10 \%$, so the inconsistency is acceptable.

Weight of Sub-criteria 5 (Influences to other component process)

In the Following Table, pairwise comparison matrix for weight of sub-criteria 5 (Other handtractor components/a, other product components/ b) are shown.

\section{Score of Alternatives under criterion 1}

Hand tractor product is operated normally in the mud wallow. This condition makes team chooses material which has good corrosive resistance in water or mood. If it continually incurs water, corrosion in graphitic stage of FC 25 will occur.Then ST 37,compound of Fe-C-S-P$\mathrm{Al}$, is a good corrosive resistance if rate of $\mathrm{S}$ and $\mathrm{P}$ is small (Bodude et al., 2012). So, assessment of each alternative can be performed as follows.

By equation (1), (2), and (3), CR is obtained $7.04 \%$ (since CR is smaller than $10 \%$, so the inconsistency is acceptable)

\section{Score of Alternatives under sub criterion $2 a$}

In the Following Table, pairwise comparison matrix for weight of alternative under subcriterion 2a (Manufacturability- Availability of Facility) is shown. The Initial design is done in casting department. In fact, the company doesn't 
Table 15. Alternatives Design Score under criterion 3

\begin{tabular}{|l|c|c|c|c|c|}
\cline { 2 - 6 } \multicolumn{1}{c|}{} & Max Load (kN) & Max Operation Load (kN) & Load Margin & percentages & score \\
\hline Initial & 211.68 & 57.4 & 154.28 & $53 \%$ & 0.53 \\
\hline Design 1 & 118.8 & 57.4 & 61.4 & $21 \%$ & 0.21 \\
\hline Design 2 & 131.6 & 57.4 & 74.2 & $26 \%$ & 0.26 \\
\cline { 2 - 5 } & & total & 289.88 & \multicolumn{2}{c}{} \\
\cline { 2 - 5 } & \multicolumn{2}{c}{}
\end{tabular}

have the facility to perform this process. Both new designs can be processed in shop, but we have to create new dies for plate metal forming.

By equation (1), (2), and (3), CR is obtained $0.00 \%$ (since $\mathrm{CR}$ is smaller than $10 \%$, so inconsistency is acceptable)

\section{Score of Alternatives under sub criterion $2 b$}

In the Following Table, pairwise comparison matrix for weight of alternatives with respect to sub-criterion 2b (Manufacturability- Machiningability) are shown.

$\mathrm{CR}=1.3 \%$ (since $\mathrm{CR}$ is smaller than $10 \%$, so inconsistency is acceptable)

\section{Score of Alternatives in sub criterion $2 c$}

In the Following Table, pairwise comparison matrices for weight of alternatives with respect to sub-criteria 2c (Manufacturability- Assembling- ability) is shown. The initial design is the easiest design for assembly. It only consists of two parts. Design 2 is more difficult than Design 1, Design 2 has more part than Design 1.

$\mathrm{CR}=2.7 \%$ (since $\mathrm{CR}$ is smaller than $10 \%$, so inconsistency is acceptable)

\section{Score of Alternatives under criterion 3}

In the Following Table, pairwise comparison matrix for weight of alternatives with respect to criterion 3(Capability to detain maximum operation load) is shown. It is calculated based on margin load force between maximum operation load and maximum load that can be detained.

\section{Score of Alternatives under criterion 4}

In the Following Table, pairwise comparison matrix for weight of alternatives with respect to criterion4 (material availability in market) is shown. Both new designs use ST 37 plate.

Table 16. Alternatives Design Score under criterion 4

\begin{tabular}{|c|c|c|c|c|c|c|c|c|}
\hline & Initial & Design 1 & Design 2 & \multicolumn{3}{|c|}{$\mathbf{b}(\mathbf{i}, \mathbf{j})$} & $\Sigma \mathbf{b}$ & Score \\
\hline Initial & 1.00 & 0.20 & 0.20 & 0.09 & 0.09 & 0.09 & 0.3 & 0.09 \\
\hline Design 1 & 5.00 & 1.00 & 1.00 & 0.45 & 0.45 & 0.45 & 1.4 & 0.45 \\
\hline Design 2 & 5.00 & 1.00 & 1.00 & 0.45 & 0.45 & 0.45 & 1.4 & 0.45 \\
\hline total & 11.0 & 2.2 & 2.2 & & & Total & 3.0 & \\
\hline
\end{tabular}

Table 17. Alternatives Design Score in sub-criterion 5a

\begin{tabular}{|c|c|c|c|c|c|c|c|c|}
\hline & Initial & Design 1 & Design 2 & \multicolumn{3}{|c|}{$\mathbf{b}(\mathbf{i}, \mathbf{j})$} & $\mathbf{\Sigma b}$ & Score \\
\hline Initial & 1.00 & 2.00 & 3.00 & 0.55 & 0.57 & 0.50 & 1.6 & 0.54 \\
\hline Design 1 & 0.50 & 1.00 & 2.00 & 0.27 & 0.29 & 0.33 & 0.9 & 0.30 \\
\hline Design 2 & 0.33 & 0.50 & 1.00 & 0.18 & 0.14 & 0.17 & 0.5 & 0.16 \\
\hline total & 1.8 & 3.5 & 6.0 & & & Total & 3.0 & \\
\hline
\end{tabular}


Table 18. Alternativ Scoreunder Sub-Criterion 5b

\begin{tabular}{|c|c|c|c|c|c|c|c|c|}
\hline & Initial & Design 1 & Design 2 & \multicolumn{3}{|c|}{$\mathbf{b}(\mathbf{i}, \mathbf{j})$} & $\Sigma \mathbf{b}$ & Score \\
\hline Initial & 1.00 & 3.00 & 3.00 & 0.60 & 0.67 & 0.50 & 1.8 & 0.59 \\
\hline Design 1 & 0.33 & 1.00 & 2.00 & 0.20 & 0.22 & 0.33 & 0.8 & 0.25 \\
\hline Design 2 & 0.33 & 0.50 & 1.00 & 0.20 & 0.11 & 0.17 & 0.5 & 0.16 \\
\hline total & 1.7 & 4.5 & 6.0 & & & Total & 3.0 & \\
\hline
\end{tabular}

Table 19. Total score recapitulation of positive criteria

\begin{tabular}{lc}
\hline \multicolumn{1}{c}{ Alternatives } & Total Score \\
\hline Initial & 0.286 \\
Design 1 & 0.389 \\
Design 2 & 0.325 \\
\hline
\end{tabular}

ST 37 has been used by the company for other components of product. It is standard material where can commonly be found in the markets, so it can be easily supplied. Unlike ST 37, the initial design is used FC 25 which has to be ordered to subcontractor.

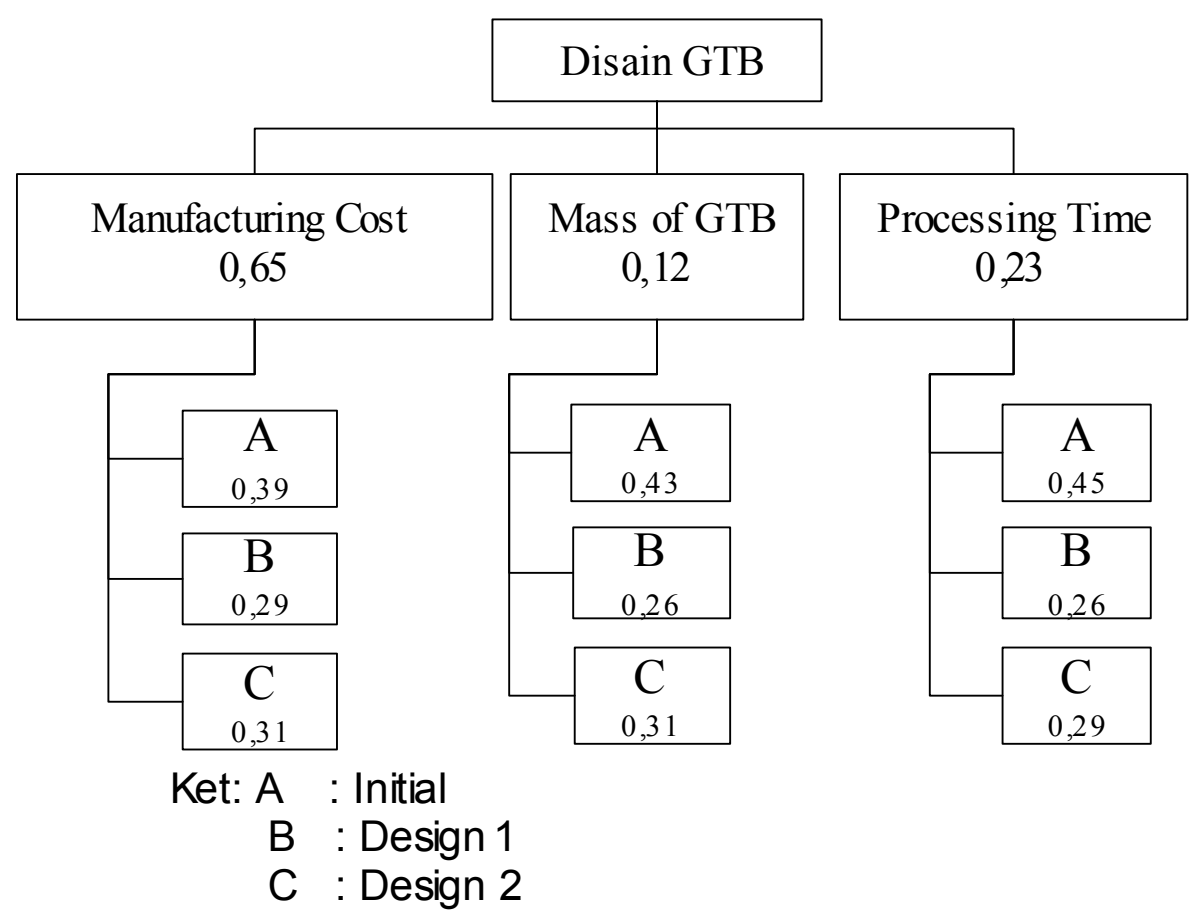

Figure 8. Priority Hierarchy of negative criteria

Table 20. Weight of negative criteria

\begin{tabular}{|c|c|c|c|c|c|c|c|c|}
\hline \multirow[b]{2}{*}{ Manufacturing Cost } & \multirow{2}{*}{$\begin{array}{l}\text { Manufacturing } \\
\text { Cost } \\
1.00 \\
\end{array}$} & \multirow{2}{*}{$\begin{array}{l}\text { Mass of } \\
\text { GTB } \\
5.00 \\
\end{array}$} & \multirow{2}{*}{$\begin{array}{l}\text { Processing } \\
\text { time } \\
3.00 \\
\end{array}$} & \multicolumn{3}{|c|}{$\mathbf{b}(\mathbf{i}, \mathbf{j})$} & \multirow{2}{*}{\begin{tabular}{|l|}
$\mathbf{z} \mathbf{b}$ \\
1.9 \\
\end{tabular}} & \multirow{2}{*}{\begin{tabular}{|l|} 
Score \\
0.65 \\
\end{tabular}} \\
\hline & & & & 0.65 & 0.63 & 0.67 & & \\
\hline Mass of GTB & 0.20 & 1.00 & 0.50 & 0.13 & 0.13 & 0.11 & 0.4 & 0.12 \\
\hline Processing time & 0.33 & 2.00 & 1.00 & 0.22 & 0.25 & 0.22 & 0.7 & 0.23 \\
\hline total & 1.5 & 8.0 & 4.5 & & & Total & 3.0 & \\
\hline
\end{tabular}


Table 21. Score of alternatives in Manufacturing Cost Criterion

\begin{tabular}{|l|c|c|}
\cline { 2 - 3 } \multicolumn{1}{c|}{} & Manufacturing Cost (Rp) & score \\
\hline Initial & $429,671.74$ & 0.39 \\
\hline Design 1 & $322,864.97$ & 0.29 \\
\hline Design 2 & $345,301.39$ & 0.31 \\
\hline total & $1,097,838.10$ & \multicolumn{1}{|c}{} \\
\cline { 1 - 2 } & \multicolumn{2}{c}{} \\
\hline
\end{tabular}

$\mathrm{CR}=0,0 \%$ (since $\mathrm{CR}$ is smaller than $10 \%$, so inconsistency is acceptable)

\section{Score of Alternativesunder sub-criterion $5 \boldsymbol{a}$}

In the Following Table, pairwise comparison matrix for weight of alternatives with respect to sub-criterion5a (Influences to other component process-Others hand tractor component) is shown;

$\mathrm{CR}=1,3 \%$ (since $\mathrm{CR}$ is smaller than $10 \%$, so inconsistency is acceptable)

\section{Score of Alternatives under sub- criterion5b}

In the Following Table, pairwise comparison matrix for weight of alternatives with respect to

Table 22. Alternatives score in Mass of GTB

\begin{tabular}{|l|c|c|}
\cline { 2 - 3 } \multicolumn{1}{c|}{} & Mass $(\mathbf{K g})$ & score \\
\hline Initial & 36.00 & 0.43 \\
\hline Design 1 & 22.00 & 0.26 \\
\hline Design 2 & 26.00 & 0.31 \\
\hline total & 84.00 & \\
\hline
\end{tabular}

Table 23. Score of Alternatives in Processing Time criterion

\begin{tabular}{|l|l|l|}
\cline { 2 - 3 } \multicolumn{1}{c|}{} & Processing time (minute) & score \\
\hline Initial & 898.65 & 0.45 \\
\hline Design 1 & 518.14 & 0.26 \\
\hline Design 2 & 565.31 & 0.29 \\
\hline total & 1982.10 & \multicolumn{1}{|c}{} \\
\cline { 1 - 2 } & \multicolumn{2}{|c}{}
\end{tabular}

sub-criterion5b (Influences to other component process-Others product component) is shown;

$\mathrm{CR}=8,1 \%$ (since $\mathrm{CR}$ is smaller than $10 \%$, so inconsistency is acceptable)

So, for positive criterion, total score of each alternative resulted by multiplying each criterion and sub criterion with each alternative weight. Those total score can be summarized as follows;

Negative criterions are a criterion which is the less the better. The criteria involved in this type are criteria 6,7, and 8 (Manufacturing cost, Mass of GTB Design and Processing time).

\section{Weight of Criteria}

The following table show pair-wise comparison matrix among three criteria.

$\mathrm{CR}=0,6 \%$ (since $\mathrm{CR}$ is smaller than $10 \%$, so inconsistency is acceptable)

\section{Score of Alternatives under Manufacturing Cost Criterion}

In the Following Table, Alternatives' score with respect to Manufacturing Cost Criterion is shown. The score is obtained by calculating percentage of manufacturing cost of each alternative.

\section{Score of Alternatives under Mass of GTB Criterion}

In the Following Table, pairwise comparison matrix for weight of alternatives with respect to mass of GTB criterion is shown.As well as the manufacturing cost criterion, the alternatives' score are obtained by calculating the each percentage of the total.

\section{Score of Alternatives under Processing Time criterion}

In the Following Table, pairwise comparison matrix for weight of alternatives with respect to in Processing Time Criteria is shown. The scores are percentage of each processing time.

So, for negative criterion, total score of each alternative is obtained by multiplying each criterion with each alternative score. It is shown in the following Table. 
Table 24. Total score recapitulation of Negative criteria

\begin{tabular}{ll}
\multicolumn{1}{c}{ Alternatives } & \multicolumn{1}{c}{ Total Score } \\
\hline Initial & 0.410 \\
Design 1 & 0.283 \\
Design 2 & 0.307 \\
\hline
\end{tabular}

The best alternative selection is performed by considering two criteria (positive and negative). Because of the characteristics of both are different, then the selection is conducted by calculating ratio.The best alternative is the one who has the highest ratio between positive and negative criteria.

$\begin{array}{lll}\text { Initial } & = & 0,286 \\ & =0,410 \\ \text { Design 1 } & = & 0,698 \\ & =0,389 \\ \text { Design 2 } & = & 0,323 \\ & = & 0,307 \\ & =\end{array}$

The greatest ratio is Design 1's.

\section{CONCLUSION}

Based on the seven criteria and five sub-criteria (Material corrosion resistance, Manufacturability [Availability of Facility, Machining-ability, Assembling-ability], The ability of the design to withstand the maximum load operation, Material availability in market, Influences to other component process [Others hand tractor component, Others product component], Manufacturing cost, Mass of GTB, and Processing time), Design 1 is admitted as the best design among three (Initial Design, Design 1 and Design 2).

\section{REFERENCES}

Atuahene-Gima, K. and Li, H. 2004. Strategic Decision Comprehensiveness and New Product
Development Outcomes In New Technology Ventures, Academy of Management Journal, 47 (4), 583-597.

Barajas, M. and Agard, B. 2008. A Ranking Procedure for Fuzzy Decision-Making in Product Design, Proceedings of IDMME - Virtual Concept.

Bodude, M., Adeosun, S.O., and Ayoola W.A. 2012. Comparative Studies on Mechanical and Corrosion Characteristics of API 5LX60 STEEL and RST 37-2 STEEL, Journal of Emerging Trends in Engineering and Applied Sciences (JETEAS) , 3 (1), 137-143.

Battistoni, E. Colladon A.F., Scarabotti, L., and Schiraldi, M.M. 2013. Analytic Hierarchy Process for New Product Development, International Journal of Engineering Business Management, 5 (1).

Boothroyd, G., and Dewhurst P. 2002. Product Design for Manufacture and Assembly (DfMA). Wakefield, Boothroyd Dewhurst Inc.

Cariaga, I., El. Dirably, T. and Osman, H. 2007. Integrating Value Analysis \& Quality Function Deployment for evaluating design alternatives, Journal of Construction Engineering and Management, 133 (10), 761-770.

Coelho, A.M.G. and Mourao A.J.F., 2007. Axiomatic Design as Support for Decision- Making in a Design for Manufacturing Context: A Case Study, International Journal of Production Economics, 109 (1-2), 81-89.

Luo, L., Kannan, P.K. and Ratchford, B.T., 2008. Incorporating Subjective Characteristics in Product Design and Evaluations, Journal of Marketing Research, XLV, 450-461.

Norton, R.L. 2014. Machine Design: An Integrated Approach, fifth edition, Prentice Hall.

Rosen, M.A., and Kishawy, H.A., 2012. Sustainable Manufacturing and Design: Concepts, Practices and Needs, Sustainability, 4.

Saaty, T.L., 1990. The Analytical Hierarchy Process: Planning, Priority Setting, Resource Allocation. Pittsburgh University Pers.

Saaty, T.L., 2008. Decision Making with the Analytic Hierarchy Process, Int. J. Services Sciences, 1 (1).

Seram, N. 2013. Decision Making In Product Development-A Review of The Literature, International Journal of Engineering and Applied Sciences, 2 (4), 1-11.

Singal, R.K., Singal, M. and Singal R. 2008. Fundamentals of Machining and Machine Tools, I. K. International Pvt. Ltd.

Ulrich, K.T. and Eppinger, S.D. 2000. Product Design and Development, 2nd Edition, London, McGrawHill Co. Inc. 